\title{
Mineralization of carbon, nitrogen, phosphorus and sulphur from different organic wastes in silty clay loam soils
}

\author{
Amit Mishra1, Narendra Kumar ${ }^{2}$, Rajiv Kumar ${ }^{3}$, Robin Kumar ${ }^{4}$, Dinesh Tomar \\ ${ }^{1}$ International Rice Research Institute, India, Modipuram, Meerut-250110 (Uttar Pradesh), INDIA \\ ${ }^{2}$ Department of Soil Science, Collage of Agriculture, GBPUA\&T, Pantnagar-263145 (Uttarakhand), INDIA \\ ${ }^{3}$ Departments of Agronomy, SVPUAT, Modipuram, Meerut-250110 (Uttar Pradesh), INDIA \\ ${ }^{4}$ Departments of Soil Science, SVPUAT, Modipuram, Meerut-250110 (Uttar Pradesh), INDIA \\ ${ }^{5}$ Departments of Soil Science, CCSHAU, Hisar - 125004 (Haryana), INDIA \\ *Corresponding author. E-mail: khatiyanr@gmail.com \\ Received: September 4, 2015; Revised received: November 27, 2015; Accepted: January 10, 2016
}

\begin{abstract}
Mineralization of carbon, nitrogen, phosphorus and suphur was studied by incubating soil samples for 90 days at $30^{\circ} \mathrm{C}$ temperature with four different organic materials viz. Press mud, sugarcane trash, paper mill bagasse and pine needle. The results showed that the carbon mineralization in soil was significantly higher from sugarcane trash followed by press mud as compared to control. The cumulative percent of carbon mineralization increased with incubation period and maximum mineralization was recorded at $90 \mathrm{DOI}$ (days after incubation). The maximum cumulative percent $\mathrm{N}$-mineralization $(16.88 \%$ ) in soil was shown by paper mill bagasse followed by sugarcane trash and pine needle. The percent $\mathrm{N}$-mineralization from all added organic amendments increased incubation period up to 45days of incubation DOI (days after incubation) after then it gradually declined, while the pine needles showed maximum cumulative P-mineralization in soil followed by sugarcane trash while minimum was recorded from press mud. The paper mill bagasse showed highest cumulative S-mineralization in soil followed by sugarcane trash. Irrespective of organic wastes, cumulative S-mineralization significantly increased after 15 days of incubation up to 45 days later on it showed declined trend. Among the organic wastes, sugarcane trash showed maximum Cmineralization in soil exhibited fast decomposition in comparison to other wastes. So, it can be used for composting. The paper mill bagasse showed more $\mathrm{N}$ and $\mathrm{S}$ mineralization while maximum mineralization of $\mathrm{P}$ was found in pine needle. The press mud and sugarcane trash showed potential for short duration enriched compost.
\end{abstract}

Keywords: Mineralization, Paper mill bagasse, Press mud, Pine needle, Sugarcane trash

\section{INTRODUCTION}

The modern day intensive crop cultivation requires the use of chemical fertilizers, which are expensive in developing countries. Therefore, the current trend is to explore the possibility of supplementing chemical fertilizers with organic ones, particularly the recycling of organic wastes through composting. India has a vast resource of organic wastes with nutrient potential of about 6 million tonnes of nitrogen, phosphorus and potassium. About 2 million tonnes of press mud is being produced annually from sugar factories (Gaur et $a l .$, 1990). Sundra (2002) indicated that press mud produced in a sugar mill is about 4 per cent of cane crushed. That is, a 2500 TCD mill produces about 100 tonnes of press mud per day and in a crushing season of 150 days the total quantity of press mud produced by such a mill is approximately 15000 tonnes.

Pal (1995) reported that the Pine (Pinus rorburghii) is a dominant species in U.P. hills (presently Uttaranchal State) and occupies about 30 per cent of the total forest area. Most of these organic wastes are either burnt or used as fillers due to slow rate of decomposition. Sundra (2002) reported that sugarcane produces huge quantity of foliage, about 40 per cent of total biomass. On an average, the amount of sugarcane trash produced about 15 to $20 \mathrm{t} \mathrm{ha}^{-1}$. However, quantity varies with variety and crop growth. The trash contains on an average $0.35 \% \mathrm{~N}, 0.13 \% \mathrm{P}_{2} \mathrm{O}_{5}$ and $0.65 \% \mathrm{~K}_{2} \mathrm{O}$. That is for every tonne of sugarcane trash, nutrient availability is $3.5 \mathrm{~kg} \mathrm{~N}, 1.3 \mathrm{~kg} \mathrm{P}_{2} \mathrm{O}_{5}$ and $6.5 \mathrm{~kg} \mathrm{~K}_{2} \mathrm{O}$. Thus, from a hectare of sugar cane crop, around $50 \mathrm{~kg} \mathrm{~N}, 20 \mathrm{~kg}$ $\mathrm{P}_{2} \mathrm{O}_{5}$ and $100 \mathrm{~kg} \mathrm{~K} \mathrm{~K}_{2} \mathrm{O}$ can be recovered from trash alone.

The use of these organic substances in agriculture is very low because they have low quantity of plant nutrients and also the rate of decomposing is very slow. For the proper utilization of these materials in agriculture, it is necessary to convert them in good quality compost. The use of organic waste in the amendment of agricultural soils can be beneficial for crops, and at the same time, provide an efficient and cost-effective method for its disposal. Many authors have reported that different types of organic waste can improve 
physical, chemical, and biological properties of soils (Clark et al., 1998; Whalen et al., 2000). Adding organic wastes to the soil can increase total $\mathrm{N}$, organic matter, microbial population, enzyme activity, moisture retention, $\mathrm{pH}$ buffering capacity and crop yields can be increased (Dick and Christ, 1995). The most immediate impact of organic waste application is on the availability of nitrogen to the subsequent crop, as a consequence of mineralization-immobilization processes (Hadas et al., 2004). During the microbial decomposition of plant residues, the preservation of released biomolecules/inorganic nutrients is essential to avoid losses and enhance the efficiency of recycling (Canellasa et al., 2010). The study on nutrient supply capacity of these organic wastes in silty loam soil is very few and possibilities to use in preparation enriched compost are not well known. Therefore, incubation study was conducted with specific objective to assess mineralization potential of different organic wastes.

\section{MATERIALS AND METHODS}

Incubation experiment was carried out using the upper layer $(0-15 \mathrm{~cm})$ of a Molisol. The soil, from Crop Research Centre (CRC), experimental farm at Govind Ballabh Pant University of Agriculture and Technology (GBUA\&T) Pantnagar, particle size distribution of $18.5 \mathrm{~g} \mathrm{~kg}^{-1}$ sand, $47.5 \mathrm{~g} \mathrm{~kg}^{-1}$ silt and $34 \mathrm{~g} \mathrm{~kg}^{-1}$ clay, was air dried at room temperature, and sieved to pass a $2 \mathrm{~mm}$ mesh. Four organic wastes, previously ground to pass a $0.75 \mathrm{~mm}$ sieve, and dried at $35 \mathrm{C}$ for $48 \mathrm{~h}$ were individually mixed with the soil. The organic wastes were composted pine leaves, press mud, paper mill bagasse and sugarcane trash. The soil and each waste were characterized chemically (Table 1).

\section{Mineralization of organic wastes}

Carbon mineralization: Mineralization of carbon was studied by incubating soil samples for 90 days at $30^{\circ} \mathrm{C}$ temperature. The organic materials were added at the rate of 0.5 per cent carbon basis at 60 per cent moisture regime. Five treatment were evaluated with three replications viz. $\mathrm{T}_{1}$ : Un amended soil, $\mathrm{T}_{2}$ : Soil + Press mud, $\mathrm{T}_{3}$ : Soil + sugarcane trash, $\mathrm{T}_{4}$ : Soil + paper mill bagasse and $\mathrm{T}_{5}$ : soil + pine needle.

One hundred gram sieved $(<2 \mathrm{~mm})$ air-dried soil was taken in a $500 \mathrm{ml}$ conical flask and the above treatments were imposed. A tube containing $10 \mathrm{ml}$ of $1 \mathrm{~N}$ $\mathrm{NaOH}$ was hung in each flask with the help of a thread tied with tube mouth. The flasks were air tightly closed with a robber cork, sealed with wax and incubated at $30^{\circ} \mathrm{C}$. $\mathrm{CO}_{2}$ evolution readings were taken daily for $1^{\text {st }}$ week, trice in the $2^{\text {nd }}$ week, twice in $3^{\text {rd }}$ week and then taken at weekly intervals up to 90 days (Gaur et al., 1971).

Mineralization of nitrogen, phosphorus and sulphur: Mineralization of N, P and S were studied by incubating soil samples at $30^{\circ} \mathrm{C}$ temperature with four different organic materials viz. Press mud, sugarcane trash, paper mill bagasse and pine needle added at the rate of 0.5 per cent carbon basis (Table 5) at 60 per cent moisture regime. Following five treatments were conducted in completely randomized block design (CRD) design with replication three.

$\mathrm{T}_{1}$ Soil + Press mud

$\mathrm{T}_{2}$ Soil + Sugarcane

$\mathrm{T}_{3}$ Soil + Paper mill bagasse

$\mathrm{T}_{4}$ Soil + pine needle

Ten gram soil was taken in the $100 \mathrm{ml}$ capacity plastic bottles and above treatments was imposed. The incubation temperature was maintained at $30{ }^{0} \mathrm{C}$ and the observations were recorded at 1, 5, 10, 15, 30, 45, 60, 75 and 90 days. Separate bottles were removed at each interval and for each estimation of N, P and S.

Nitrogen mineralization: For mineral $\mathrm{N}$ extraction, $100 \mathrm{ml}$ of $2 \mathrm{M} \mathrm{KCl}$ was added to the bottle, shaked for 30 minutes, filtered through Whatman No. 42 filter paper and mineral $\mathrm{N}$ was determined in the extract by steam distillation method (Keeney and Nelson, 1982).

Phosphorus mineralization: For P extraction $200 \mathrm{ml}$ of $0.5 \mathrm{M} \mathrm{NaHCO} 3(\mathrm{pH} 8.5)$ and a spoonful of Darco G 60 Charcoal was added in the bottles and shaken for 30 minutes, filtered through Whatman No. 42 filter paper and $\mathrm{P}$ was determined by in the extract by method of John (1970).

Sulphur mineralization: For $\mathrm{S}$ extraction, $50 \mathrm{ml}$ of 0.15 per cent $\mathrm{CaCl}_{2}$ was added in the bottles and shaken for 30 minutes, filtered through Whatman No. 42 filter paper and S content in the extract was determined by method of Palaskar et al. (1981).

Statistical analysis: The experimental data were analyzed by using standard procedure for a completely randomized block design (CRD) with the help of a computer applying analysis of variance (ANOVA) technique (Snedecor and Cochran, 1971). The differences among treatments were compared by applying ' $F$ ' test of significance at 5 per cent level of probability.

\section{RESULTS AND DISCUSSION}

Carbon mineralization: It is evident from the data that mean carbon mineralization from different organic wastes in soil, irrespective of incubation period, was significantly higher than unamended soil. The pattern of carbon released from different amendments was in the order of sugarcane trash $>$ press mud $>$ paper mill bagasse $>$ pine needle. The maximum mean carbon mineralization (33.55 per cent) was observed from sugarcane trash which was $99.46,75.14$ and 63.65 per cent, respectively more than pine needle, paper mill bagasse and press mud. The carbon mineralization was increased with incubation period irrespective of organic wastes up to 95 days. However, the significant increases in carbon mineralization were recorded after 4 days of incubation over initial day. The maximum cumulative carbon mineralization $(36.78 \%)$ was registered at $95^{\text {th }}$ day of incubation. The added organic 
Table 1. Chemical properties of different organic wastes.

\begin{tabular}{lcc}
\hline Parameter & OC (\%) & Total N (\%) \\
\hline Press mud & 40.29 & 1.22 \\
Sugarcane trash & 45.24 & 0.44 \\
Pine needle & 49.41 & 0.41 \\
Paper mill bagasse & 55.92 & 0.36 \\
\hline \multicolumn{2}{|c}{ Table 2. Initial soil properties of incubated soil. } \\
\hline \multicolumn{2}{l}{ Properties } & Value \\
\hline Texture & Silty clay loam \\
pH $(1: 2$, Soil : Water ratio & 7.20 \\
Bulk density Mg m & & 1.43 \\
Electrical conductivity dSm & $(1: 2)$ & 0.41 \\
Organic carbon $(\%)$ & 0.73 \\
Available N $\left(\mathrm{kg} \mathrm{ha}^{-1}\right)$ & 220.50 \\
Available P $\left(\mathrm{kg} \mathrm{ha}^{-1}\right)$ & 18.20 \\
Available K $\left(\mathrm{kg} \mathrm{ha}^{-1}\right)$ & 125.10 \\
\hline
\end{tabular}

amendments showed significant interaction with incubation time. In un amended soil, significant $\mathrm{C}$ mineralization was observed after 55 days of incubation. The paper mill bagasse showed significant increase in $\mathrm{C}$ mineralization after $7^{\text {th }}$ day, pine needle and press mud after $6^{\text {th }}$ day and sugarcane trash after $4^{\text {th }}$ day of incubation. On $5^{\text {th }}$ day of incubation sugarcane trash showed 150.8 per cent significantly more carbon mineralization in comparison to paper mill bagasse, however, after $6^{\text {th }}$ days sugarcane trash gave highest and significant $\mathrm{C}$ mineralization over other amendments. The press mud mineralized significantly higher carbon than pine needle after 41 days (Table 3 ).

The cumulative per cent carbon mineralization from soil added organic wastes (pine needle, paper mill bagasse, sugarcane trash and press mud) was significantly higher as compared to control. It may be due to microbial degradation of newly added organic amendments in soil which evolved more $\mathrm{CO}_{2}$ upon oxidation, therefore more carbon was mineralized. Dutta (2001) and Paul and Solaiman (2002) have also reported more $\mathrm{C}$ mineralization from organic wastes incubated soil than the control. Results also indicated positive relationship between cumulative $\mathrm{C}$ mineralization and incubation period. It was probably because in the beginning of decomposition more complex materials were present in wastes and lesser microbial number as well activity was low as the decomposition preceded the microbial number and activity increased which increased cumulative $\mathrm{C}$ mineralization. These findings are in support of Paul and Salaiman (2002) and Pareek et al. (2003) who demonstrated increased C mineralization with increased incubation period and sugarcane trash have more carbon mineralization than the press mud.. Among different wastes, sugarcane trash showed maximum $\mathrm{C}$ mineralization while minimum $\mathrm{C}$ mineralization was found with press mud. It might be due to low amount of cellulose and lignin contents in sugarcane trash, which are resistant for microbial attack while press mud may have already decomposed and complex carbohydrates and other chemicals, which reduced decomposition and finally $\mathrm{C}$ mineralization.

\begin{tabular}{cccc} 
C:N & Total P (\%) & Total K (\%) & Total S (\%) \\
\hline 33.02 & 0.536 & 0.436 & 0.127 \\
102.81 & 0.295 & 0.411 & 0.102 \\
120.51 & 0.129 & 0.231 & 0.142 \\
155.33 & 0.159 & 0.334 & 0.031 \\
\hline
\end{tabular}

Anetta and Joanna (2014) reported that a long-term intensive use of the soil fertilised with manure cannot ensure a positive total organic carbon balance.

Nitrogen mineralization: The cumulative per cent nitrogen mineralization in soil increased irrespective of added organic amendments up to 45 days of incubation after then it gradually declined. The maximum $\mathrm{N}$ mineralization $(20.19 \%)$ was recorded at $45^{\text {th }}$ day of incubation. The significant $(\mathrm{P}<0.05)$ increase in nitrogen mineralization was observed after 15 days up to 45 days of incubation in comparison to initial day. After 90 days it reached to its initial level i.e. first day. The slow rate of $\mathrm{N}$ mineralization may possibly be due to slow decomposition of organic wastes by micro organism because of presence of higher molecular weight compounds, later on decomposition rate increased due to increase in microbial population and activity by getting $\mathrm{C}$ and nutrients from organic wastes. After a certain period the available $\mathrm{C}$ and nutrients were exhausted by micro organisms and mineralization of $\mathrm{N}$ was decreased due to reduction in microbial population. Similar finding have been reported by Dhull et al. (1998) and Adeiran et al. (2003) who revealed that $\mathrm{N}$ mineralization increased with increase in incubation period up to a certain stage and then decreased. Moharana et al., (2015) reported that the application of compost alone caused no immobilization of available $\mathrm{N}$, indicating that organic manures having narrow $\mathrm{C} / \mathrm{N}$ ratio enhances mineralization of soil $\mathrm{N}$. Moreover, large proportion of $\mathrm{N}$ remains in the organic form in the compost treated soils, with time, this organic $\mathrm{N}$ undergoes mineralization and made available for plants. The pattern of mineralization depends on the $\mathrm{N}$ content of organic manure and amount applied.

Irrespective of incubation period, the per cent cumulative nitrogen mineralization was maximum (16.88\%) from paper mill bagasse followed by sugarcane trash and pine needle. The minimum nitrogen mineralization was exhibited from press mud. The addition of paper mill bagasse and sugarcane trash in soil showed 82.28 and 50.32 per cent significantly higher $\mathrm{N}$ mineralization than press mud. The interaction between amendments and incubation period were non significant (Table 4).

The maximum $\mathrm{N}$ mineralization was shown by paper mill bagasse, while press mud showed minimum $\mathrm{N}$ mineralization. This was possibly because of the presence of $\mathrm{N}$ in less complex compounds which released $\mathrm{N}$ at faster rate than other organic wastes while in press mud $\mathrm{N}$ may be present in more complex compounds. Pareek et al. (2003) also reported that $\mathrm{N}$ mineralization was more in paper mill bagasse than other organic 
Table 3. Cumulative per cent carbon mineralization from the carbon added through different organic wastes at 60 per cent WHC.

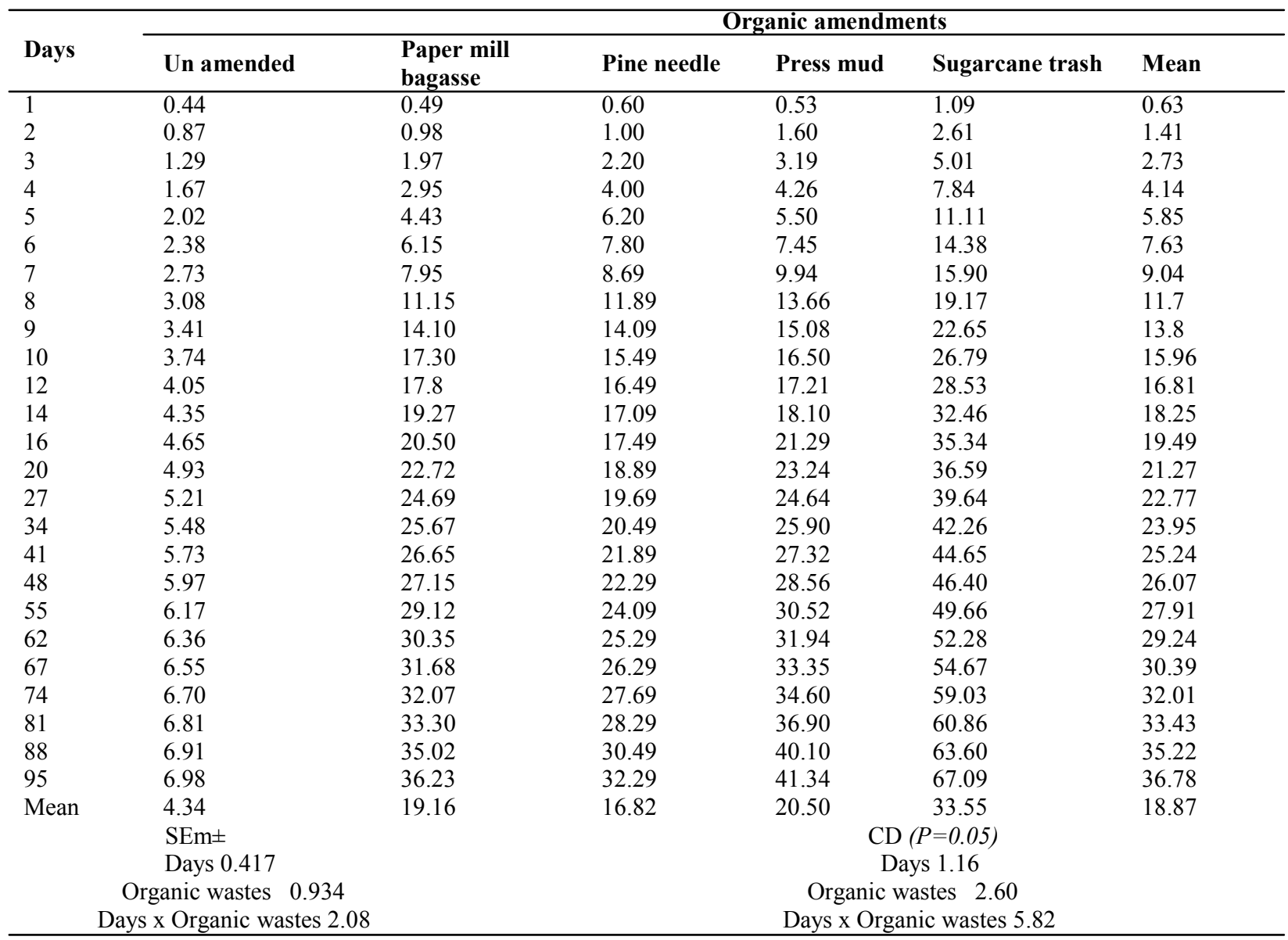

Table 4. Cumulative per cent nitrogen mineralization from the nitrogen added through different organic wastes at 60 per cent WHC.

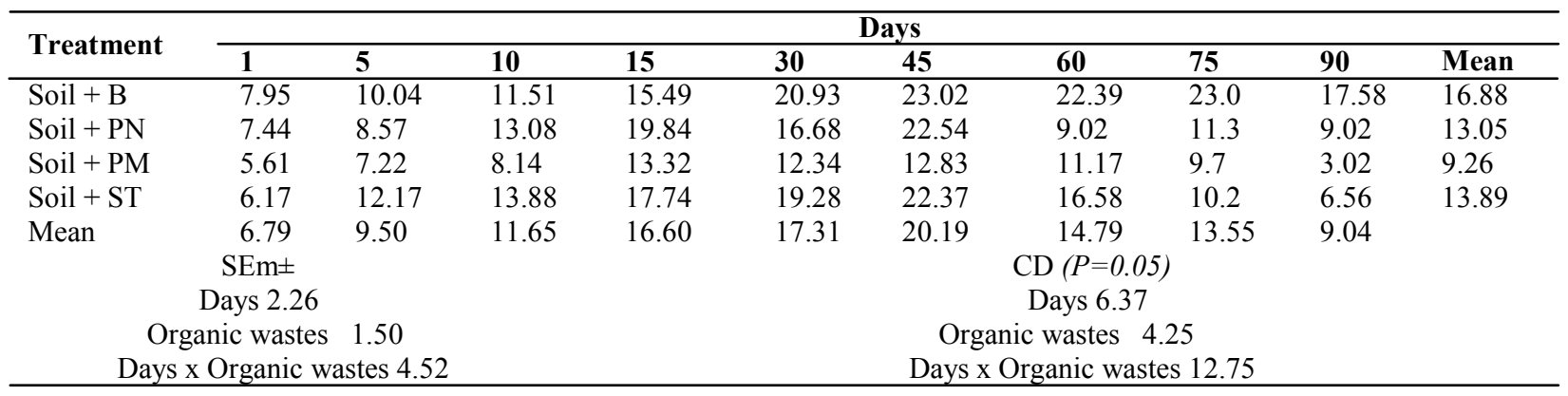

B- Paper mill bagasse, PN- Pine needle, PM-Press mud, ST- Sugarcane trash

Table 5. Cumulative per cent phosphorus mineralized from the phosphorus added through different organic wastes at 60 per cent WHC.

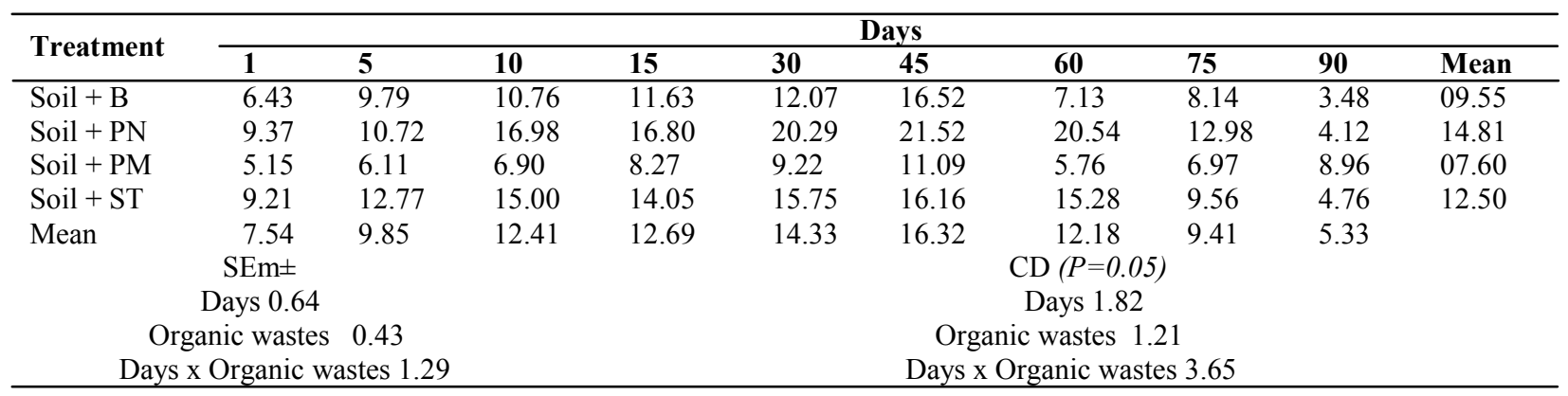

B- Paper mill bagasse, PN- Pine needle ,PM-Press mud, ST- Sugarcane trash 
Table 6. Cumulative per cent sulphur mineralized from the sulphur added through different organic wastes at 60 per cent WHC.

\begin{tabular}{|c|c|c|c|c|c|c|c|c|c|c|}
\hline \multirow{2}{*}{ Treatment } & \multicolumn{10}{|c|}{ Days } \\
\hline & 1 & 5 & 10 & 15 & 30 & 45 & 60 & 75 & 90 & Mean \\
\hline ASoil+B & 12.41 & 10.39 & 18.91 & 24.074 & 27.43 & 28.50 & 21.99 & 13.08 & 10.73 & 18.61 \\
\hline Soil+PN & 11.47 & 10.48 & 12.74 & 14.808 & 17.07 & 17.63 & 13.16 & 9.82 & 3.31 & 12.28 \\
\hline Soil+PM & 10.46 & 11.55 & 12.38 & 14.694 & 16.11 & 17.27 & 13.71 & 12.74 & 3.98 & 12.54 \\
\hline Soil+ST & 16.54 & 11.23 & 12.47 & 20.615 & 21.58 & 21.64 & 21.94 & 9.47 & 4.76 & 15.58 \\
\hline Mean & 12.72 & 10.91 & 14.12 & 18.55 & 20.55 & 21.26 & 17.70 & 11.28 & 5.69 & \\
\hline $\begin{array}{r}\mathrm{O} \\
\text { Day: }\end{array}$ & $\begin{array}{l}\mathrm{Em} \pm \\
\text { ys } 2.26 \\
\text { c wastes } \\
\text { rganic w }\end{array}$ & $\begin{array}{l}50 \\
\text { es } 4.52\end{array}$ & & & & $\begin{array}{r}\text { Org } \\
\text { Days } x\end{array}$ & $\begin{array}{l}\mathrm{D}(P=0 \\
\text { Days } 6 . \\
\text { wastes } \\
\text { ganic } \mathrm{W}\end{array}$ & $\begin{array}{l}25 \\
\text { es } 12.75 \\
\end{array}$ & & \\
\hline
\end{tabular}

B- Paper mill bagasse, PN- Pine needle, PM-Press mud, ST- Sugarcane trash

wastes.

Phosphorus mineralization: Perusal of the data cumulative phosphorus mineralization from paper mill bagasse, pine needle, press mud and sugarcane trash in soil differed significantly. The maximum phosphorus mineralization $(14.84 \%)$ was recorded with pine needle followed by sugarcane trash while minimum (7.60 $\%$ ) from press mud. Pine needle showed 37.9 and 18.72 per cent more phosphorus mineralization in comparison to paper mill bagasse and sugarcane trash. Irrespective of added material, phosphorus mineralization was increased up to 45 days after incubation then it showed significantly declined trend up to 90 days of incubation. Maximum phosphorus was mineralized at $45^{\text {th }}$ day which was significantly higher than the values of mineralized phosphorus recorded at different intervals. It may be due to production of more acids from pine needle by microbial attack because pine needle are acidic in nature and secreted organic acids solubilized more $\mathrm{P}$ in soil. On the other hand press mud was alkaline in nature, which did not release organic acids in sufficient amount; therefore, $\mathrm{P}$ mineralization was low.

The interaction effect between organic wastes and incubation period was found significant. The phosphorus mineralization significantly increased after 10 days of incubation from all the organic amendments, except press mud which significantly increased after 30 days of incubation than its initial level. However, all the amendments showed maximum mineralization up to $45^{\text {th }}$ day. Paper mill bagasse and press mud exhibited significant reduction in phosphorus mineralization after 60 days of incubation while pine needle and sugarcane trash after 75 days of incubation.

Paper mill bagasse, pine needle and sugarcane trash demonstrated significantly higher $\mathrm{P}$ mineralization than press mud up to 45 days of incubation. At $60^{\text {th }}$ day of incubation, both paper mill bagasse and press mud showed significant decline in phosphorus mineralization than pine needle and sugarcane trash. However, press mud at $75^{\text {th }}$ day of incubation and pine needle at $90^{\text {th }}$ day of incubation gave lowest phosphorus mineralization (Table 5).

The cumulative percent phosphorus mineralization was also enhanced with incubation time up to a certain period. Thereafter, it decreased. The phosphorus mineralization depended on the phosphorus solubilisation due to production of organic acids by microbial decomposition of wastes, which increased up to 45 DOI only as decomposition of organic wastes slowed down after words. Pareek et al. (2003) also found increased $\mathrm{P}$ mineralization up to 45 days and thereafter declined was trend observed. Moharana et al., (2015) observed that the Olsen-P in soil treated with any of the $\mathrm{P}$ sources declined up to 30 days of incubation which may be due to fixation of available $\mathrm{P}$ into unavailable forms.

Sulphur mineralization: It is evident from the table 6 that per cent cumulative sulphur mineralization of soil added paper mill bagasse was significantly higher than other organic wastes. The addition of sugar cane trash also mineralized significantly 24.2 and 26.87 per cent more sulphur, respectively significantly more in comparison to pine needle and press mud. However, both pine needle and Press mud were statistically comparable with each other. The pattern of sulphur mineralization from different amendments was in order of paper mill bagasse $>$ sugarcane trash $>$ press mud $>$ pine needle. The paper mill bagasse showed 19.44, 51.54 and 48.4 per cent more sulphur mineralization than sugarcane trash, Press mud and pine needle, respectively. Irrespective of organic wastes, significant increases were recorded after 15 days of incubation over initial mineralization value. However, sulphur mineralization was increased up to 45 days of incubation. Then it showed significantly declined trend at all the intervals up to 90 days. The maximum sulphur mineralization of 31.26 per cent was registered at 45 days of incubation.

The interaction of different organic wastes in soil and 
incubation period for sulphur mineralization was significant. The sulphur mineralization from paper mill bagasse significantly increased on $10^{\text {th }}$ days of incubation. After 45 days of incubation it declined significantly up to 75 days of incubation and then non significantly trend up to 90 days. Pine needle and sugar cane trash gave significant increase in sulphur mineralization on $30^{\text {th }}$ day of incubation. On the other hand, press mud exhibited maximum and significantly higher sulphur mineralization at $45^{\text {th }}$ day of incubation Sulphur mineralization from pine needle significantly reduced on $60^{\text {th }}$ day of incubation and in sugarcane trash maximum sulphur mineralization was obtained 60 days of incubation then it demonstrated significantly declined at $90^{\text {th }}$ days of incubation. Press mud showed significant decline in sulphur mineralization on $60^{\text {th }}$ and $90^{\text {th }}$ days of incubation. At initial stage sugarcane trash showed significantly more sulphur mineralization in comparison to other organic wastes. Paper mill bagasse gave maximum and significantly more mineralization at 10,30 , and $45^{\text {th }}$ day after incubation than other amendments. However, on 15 and $60^{\text {th }}$ day of incubation both paper mill bagasse and sugar cane trash showed significantly higher sulphur mineralization than pine needle and press mud. At $90^{\text {th }}$ day, significantly more amount of mineralized sulphur was observed from paper mill bagasse when compared with other wastes (Table 6).

Higher S mineralization from paper mill bagasse might be related with more microbial oxidation of sulphur in comparison to press mud. Pareek et al. (2003) also reported that mean sulphur mineralization is more in sugarcane trash followed by bagasse and lowest in press mud. The S-mineralization decreased initially up to $5^{\text {th }}$ days but after 15 day it increased significantly up to 45 days and declined later on. The decrease in S mineralization at initial stage may be due to immobilization of S because of wide C: S ratio, After some period it again increased due to the microbial activity. Later on the nutrients were consumed by microorganism and microbial number and activity was reduced which lowered the S mineralization. In the same manner, McGill and Cole (1981) also observed role of lignocellulosic micro organisms in S mineralization. Somani and Saxena (1975) reported that $S$ mineralization decreased at initial stage of decomposition. Where as in contrast, Pareek (2000) concluded that initially S mineralization increased up to a certain period and after that declaimed very rapidly. Moharana et al., (2015) reported that sulphur mineralization in the soil is typically attributed to either biological or biochemical processes. The biological route is governed by the microbes for searching their energy and the $\mathrm{S}$ is released as a by-product. The biochemical process is defined as the release of $\mathrm{S}$ from ester sulphates, through extracellular enzymatic hydrolysis.

\section{Conclusion}

The study showed that in respect of major findings cumulative percent of carbon mineralization increased with incubation period and maximum mineralization was recorded at 95 DOI. That indicates up to $90 \mathrm{DOI}$ decomposition of $\mathrm{C}$ was found. The maximum cumulative percent $\mathrm{N}$-mineralization $(16.88 \%)$ in soil was shown by paper mill bagasse followed by sugarcane trash and pine needle. Pine needles showed maximum cumulative P-mineralization in soil followed by sugarcane trash while minimum was recorded from press mud. The paper mill bagasse showed highest cumulative S-mineralization in soil followed by sugarcane trash. Irrespective of organic wastes, cumulative percent of nitrogen, phosphorus and Sulphurmineralization significantly increased up to 45 days of incubation later on it showed declined trend. These findings might be useful in to understand the release pattern of nitrogen, phosphorus and sulphur in soil and preparing enriched compost from these organic wastes. Sugarcane trash and press mud could be directly use in soil as organic amendment and good for the prepara tion of enriched compost.

\section{REFERENCES}

Adeiran, J.A., De-Baets, N., Mnkeni, P.N.S., Kiekens, L., Muyima, N.Y.O. and Thys, A. (2003). Organic wastes materials for soil fertility improvement in the border regain of the Eastern Cape, South Africa. Biol. Agric. Hortic., 20(4): 283-300.

Anetta, S. Z. and Joanna, L., (2014). The content of carbon, nitrogen, phosphorus and sulphur in soil against the activity of selected hydrolases as affected by crop rotation and fertilisation. Zemdirbyste-Agriculture, 101(4): 367-372.

Canellasa, L.P., Busato, J.G., Dobbss, L.B., Baldotto, M.A., Rumjanek, V.M and Olivares, F.L.(2010). Soil organic matter and nutrient pools under long-term nonburning management of sugar cane. Eur. J. Soil Sci., 61: 375-383.

Clark, M., W. Sean, R. Horwath, C. Shennan, and K.M. Scow. (1998). Changes in soil chemical properties resulting from organic and low-input farming practices. Agron. J., 90:662-671.

Dhull, S.K.; Singh, J.P. and Vinod, K. (1998). Kinetics of nitrogen mineralization from different organic materials in soil. Annals Biology. Ludhiana. 14(1): 113- 117.

Dick, R.P., Christ, R.A. (1995). Effects of long-term waste management and nitrogen fertilisation on availability and profile distribution of nitrogen. Soil Sci., 159: 402408.

Dutta, D.K.; Banerjee, S.K. and Gupta, S.K. (2001). Decomposition of board leafed and coniferous forest litter. $J$. Indian Soc. Soil. Sci., 49(3): 496-416.

Gaur, A.C.; Neelakantan, S. and Dargan K.S. (1990). Organic manures. $2^{\text {nd }}$ ICAR, New Delhi. pp 159.

Gaur, A.C., Sadasivam, K.V.; Vimal, O.P. and Mathur, R.S. (1971). A decomposition of organic matter in an alluvium soil: $\mathrm{CO}_{2}$ evolution microbiological and chemical transformation. Plant Soil., 34: 17-28.

Hadas, A., Kautsky, L., Mustafa, G., Kara, E.E. (2004). Rates of decomposition of plant residues and available nitrogen in soil, related to residue composition through 
simulation of carbon and nitrogen turnover. Soil Biol. Biochem., 36: 255-266.

John, M.K. (1970). Colorimetric determination of Phosphorus in soil plant material with ascorbic acid. Soil Sci., 109: 214-220.

Keeney and Nelson. (1982). Nitrogen inorganic forms. In : Methods of Soil Analysis, Part 2, $2^{\text {nd }}$ Edn. (Page, A.L. ed.) Am. Soc. Agron. Madison. pp. 648-658.

McGill, W. B. and Cole, C. V. (1981). Comparative aspects of cycling of organic carbon, nitrogen sulphur and phosphorus through soil organic matter. Geoderma, 26: 267286.

Moharana, P.C. Biswas, D.R. and Datta, S.C. (2015). Mineralization of nitrogen, phosphorus and sulphur in soil as influenced by rock phosphate enriched compost and chemical fertilizers. J. Indian Soc. Soil Sci., 63 (3): 283293.

Pal, S.S. (1995). Use of pine litter as an organic amendment for inceptisols of Garhwal region of Himalaya. J. Indian Soc. Soil. Sci., 43(3): 448-452.

Palaskar, M.S., Babrekar, P.C. and Ghosh, A.B. (1981). A rapid analytical technique to estimate sulphur in soil and plant extracts. J. Indian Soc. Soil Sci., 29: 249-256.
Pareek, N. (2000). Evolution of some sulphur supply indices Mollisols for sunflower (Helianthus annuus L.). Ph.D. Thesis. G.B.P.U.A. \& T., Pantnagar.

Pareek, R.P., Kumar, N., Pareek, N. and Singh, R.K. (2003). Organic matter recycling and enrichment. Project Progress Research Report, NATP, ICAR.

Paul, G.C. and Solaiman, A.R.M. (2002). Kinetics of carbon dioxide evolution in a sugarcane soil amended with different organic materials. Indian J. Sugarcane Tech. 17(1/2): 22-25.

Snedecor, G.W. and Cochran, W.G. (1971). Statistical methods. $6^{\text {th }}$ edn. Oxford and IBH Pub. Co., New Delhi. pp 593.

Somani, L.L. and Saxena, S.N. (1975). Effect of some organic matter source on nutrient availability, humus build up, soil physical properties and wheat yield under field conditions. Ann. Arid Zone., 14: 149-158.

Sundra (2002). Sugarcane cultivation. Vikas Publishing House (P) Ltd. pp. 271-77.

Whalen, J.K., C. Chang, G.W. Clayton, and J.P. Carefoot. (2000). Cattle manure amendments can increase the $\mathrm{pH}$ of acid soils. Soil Sci. Soc. Am. J., 64:962-966. 